\title{
Risk Assessment of Urban Lake Water Quality Based on in-situ Cyanobacterial and Total Chlorophyll-a Monitoring
}

\author{
Hazem Mohamed Kalaji ${ }^{1 *}$, Oksana Sytar ${ }^{2,3}$, Marian Brestic ${ }^{2}$, \\ Izabela Anna Samborska ${ }^{1}$, Magdalena Danuta Cetner ${ }^{1}$, Corina Carpentier ${ }^{4}$ \\ ${ }^{1}$ Department of Plant Physiology, Warsaw University of Life Sciences WULS-SGGW, \\ Nowoursynowska 159, 02-776 Warsaw, Poland \\ ${ }^{2}$ Department of Plant Physiology, Slovak University of Agriculture, \\ Tr. A. Hlinku 2, 94976 Nitra, Slovakia \\ ${ }^{3}$ Department of Plant Physiology and Ecology, Taras Shevchenko National University of Kyiv, \\ Volodymyrs'ka St. 64, 01601 Kyiv, Ukraine \\ ${ }^{4}$ Benten Water Solutions, De Nieuwesluis 2, 8064 EB Zwartsluis, the Netherlands
}

Received: 28 July 2015

Accepted: 3 December 2015

\begin{abstract}
The aim of this study was to establish a simple and cost-effective method to monitor the effects of harmful algal blooms as exemplified in Lake Powsinkowskie, and to link the monitoring results to potential health risks on the basis of established Alert Level Frameworks.

An assessment of the severity of cyanobacterial development in Lake Powsinkowskie $\left(52^{\circ} 9^{\prime} 27^{\prime \prime} \mathrm{N}\right.$, $21^{\circ} 5^{\prime} 55^{\prime \prime E}$ ), located in the Wilanów region, Warsaw, Poland, was performed to illustrate this. An Alert Level Framework based on cyanobacterial chlorophyll- $a$ measurements was applied. Measurements of cyanobacterial chlorophyll- $a$ in Lake Powsinkowskie were performed once per week at 10 locations on each side of the lake from May to July 2012. The highest algal densities were expected at the eastern side of the lake due to the use of fertilizers on the fields along the eastern shore, however, the opposite was observed. It seems that the conditions on the west side of the lake were more favourable for cyanobacterial growth.

This study shows that an indication of the overall effects of eutrophication on algal growth and the potential risk of the presence of toxic cyanobacteria can easily be obtained using relatively simple, simultaneous measurements of total and cyanobacterial chlorophyll- $a$. The Alert Level Framework based on cyanobacterial chlorophyll-a levels is a rapid and easily applicable method for determining the severity of cyanobacterial developments.

The findings of this study indicate that a reduction in nutrient loading to protect Lake Powsinkowskie's unique species richness can be achieved by informing the local residents about the effects of draining cesspools directly into the lake. Studies such as this one can thus help to support awareness-raising among lake-side residents.
\end{abstract}

Keywords: eutrophication, chlorophyll fluorescence, lakes, cyanobacteria, algae

*e-mail: hazem@kalaji.pl 


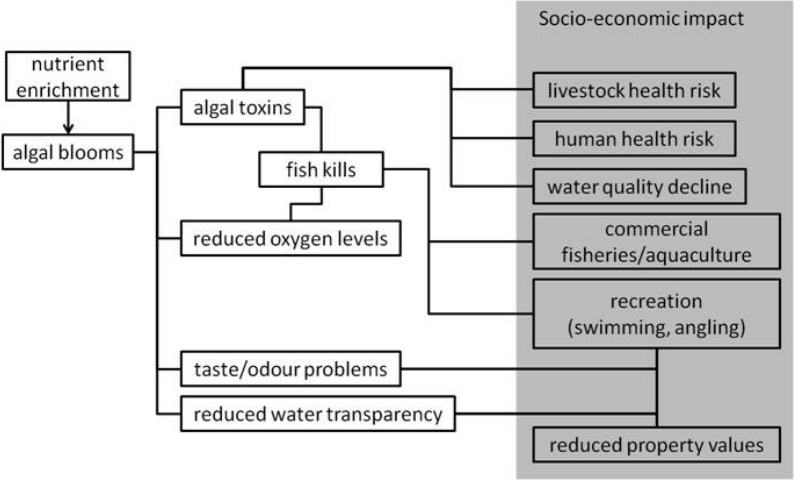

Fig. 1. Ecological effects and socio-economic impact of algal blooms resulting from nutrient enrichment.

\section{Introduction}

As in many countries, until recently urban water management in Poland has focused mainly on water supply, sewage treatment, and storm water management. Especially in rapidly expanding cities such as Warsaw, it has been difficult for the city's water management to keep pace with the dynamic increase in population and ensure the creation and maintenance of friendly urban environments [1].

In addition to the conventional purposes of urban water management, awareness of the necessity for freshwater ecosystem conservation is increasing. The presence of urban parks, park ponds, and suburban gardens can improve the "psychological well-being of city dwellers by relieving the pressure of modern urban life" [2], and their careful management can protect rare and endangered species of, e.g., invertebrates [3]. However, (sub)urban sprawl also puts significant pressure on the ecological integrity of urban lakes [3], thus also threatening the services these lakes provide to humans, such as recreation and storm water control.

Residential development as a result of population growth is associated with environmental impact, including nutrient pollution and the subsequent eutrophication of lakes [4]. Maintaining and preserving water quality in Lake Powsinkowskie on the outskirts of Warsaw has been a long-standing goal of residents and other interest groups. Given trends in regional land use, the Predictive SeasonBased Water Quality Model for Lake Powsinkowskie [5] has shown that the most immediate threat to the water quality of the lake is nutrient enrichment due to increased population and associated development near the lake. Without careful monitoring and management, Lake Powsinkowskie could change from a valued public asset into a liability, thereby raising public health concerns.

Eutrophication is known to cause serious ecosystem degradation [6,7], and to increase the incidence of harmful algal blooms $[8,9]$, resulting in various socio-economic impacts (Fig. 1). The development of cyanobacterial strains containing toxins is a common experience in polluted inland water systems all over the world, as well as in coastal waters. Thus cyanobacterial toxins (or "cyanotoxins") have become a concern for human and animal health $[9,10]$. Organisms responsible for cyanobacterial poisoning include an estimated 40 genera, but the main ones are Anabaena, Aphanizomenon, Cylindrospermopsis, Lyngbya, Microcystis, Nostoc, and Oscillatoria (Planktothrix) [11]. Toxin production by cyanobacteria appears highly variable, both within and between blooms; production and potency can also vary with time for an individual bloom [12]. Globally, the most frequently found cyanobacterial toxins in blooms from fresh and brackish waters are the cyclic peptide toxins of the microcystin and nodularin families $[11,13]$. Thus, the monitoring of cyanobacte-

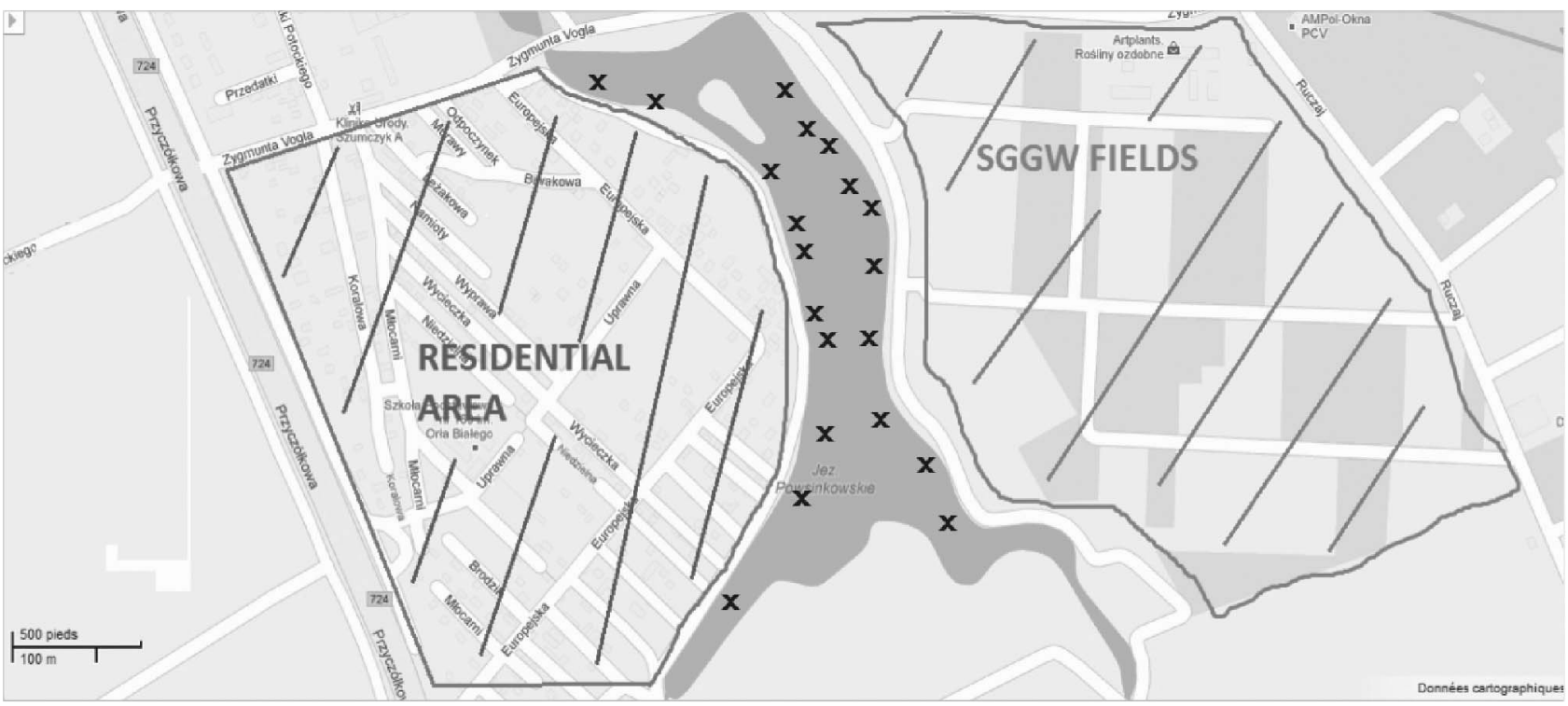

Fig. 2. Experimental area of Lake Powsinkowskie, including the residential area and the fields in use by WULS-SGGW; approximate positions in which the measurements were performed are marked with " $x$ ". 
ria is important to determine their dynamic development throughout the seasons.

The toxicity of cyanobacterial blooms in water can be determined in various ways, such as bioassays using Lemna minor [14], or analytical toxin analysis using HPLC [15]. However, determining only the toxicity itself is insufficient and needs to be accompanied by an indication of limit values beyond which an unacceptable risk for public health may occur. To this end, several researchers have identified alert levels of potentially dangerous cyanobacterial densities, and defined monitoring and management actions to reduce adverse effects on public health $[16,17]$. Despite the numerous available methods to determine the toxicity of cyanobacterial blooms in water, these alert level frameworks (as described in literature [15, 17]) are generally based on cyanobacterial cell counts, which require expensive and laborious microscopic analysis. Izydorczyk et al. [18] translated these alert levels into cyanobacterial chlorophyll-a levels for a Polish lake, allowing for a simple assessment of cyanobacterial chlorophyll-a levels using cheap(er) field methods based on fluorescence measurements.

Since information regarding the current status of the water quality in Lake Powsinkowskie is limited, the use of eutrophication indices such as those developed by Van Puijenbroek et al. [19], which are based on long-term datasets of nutrient monitoring, cannot be used in this case.

The overall goal of this study was to establish a simple and cost-effective method to monitor the effects of eutrophication in general and harmful algal blooms in particular, as exemplified in Lake Powsinkowskie; and then to link the monitoring results to potential health risks on the basis of established alert level frameworks. The two major objectives were, therefore, to:

1. Determine causes and effects of lake eutrophication on (harmful) algal bloom development, expressed as total and cyanobacterial chlorophyll-a levels.

2. Apply the alert level framework as developed by Izydorczyk et al. [18] to assess the potential health risk of harmful algal bloom formation.

\section{Materials and Methods}

\section{Study Site}

Lake Powsinkowskie $\left(52^{\circ} 9^{\prime} 27^{\prime \prime} \mathrm{N}, 21^{\circ} 5^{\prime} 55^{\prime \prime} \mathrm{E}\right)$ is situated in Warsaw's Wilanów District. The Vistula River enters the lake on the eastern side. Just north of Powsinkowskie is another lake: Lake Wilanowskie [20]. On the western side of this lake is a residential area, and on the eastern side are fields owned by the Warsaw University of Life Sciences (WULS-SGGW; Fig. 2). For many years these fields have been used for experiments using fertilizers and/or pesticides at high and normal concentrations to increase agricultural production, and - more recently - to develop more efficient water resource management concepts in relation to agricultural activities under changing climatic conditions [21, 22].

\section{Field Measurements of Chlorophyll- $a$}

Measurements of total and cyanobacterial chlorophyll$a$ in Powsinkowskie were performed from May to July 2012. The weather forecast of Warsaw reported that during these three months the temperatures in Warsaw were between 12 and $34^{\circ} \mathrm{C}$ (data from the Meteorological Institute). Wind direction is generally from west to east, so any accumulation of algal biomass as a result of water currents caused by the wind would be expected on the eastern shore of the lake, near the university's experimental fields.

Cyanobacterial and total chlorophyll-a levels were measured using an AlgaeTorch (bbe Moldaenke GmbH, Schwentinental, Germany) - a fluorescence measurement device specifically developed to perform field measurements of total chlorophyll- $a$ and cyanobacterial chlorophyll- $a$ [23]. This instrument is based on the same principle as the bbe FluoroProbe [24] and provides rapid measurement of the concentrations of cyanobacterial and total chlorophyll- $a$ in the water. Due to the fact that algae of the same division contain a similar quantity and quality of photosynthetic pigments, their fluorescence excitation spectrum (with a fixed emission wavelength at 680 $\mathrm{nm}$ ) is significant. Thus, it is possible to differentiate divisions of algae by their fluorescence excitation spectrum [25]. The bbe AlgaeTorch uses seven LEDs for fluorescence excitation. These LEDs emit light at three selected wavelengths (470 nm, $525 \mathrm{~nm}, 610 \mathrm{~nm}$; two LEDs each). An additional LED is used for turbidity estimations based on the reflected light of any particles in the water. The turbidity estimations are used to indicate the reliability of the chlorophyll- $a$ measurements. At high turbidity levels, the chlorophyll- $a$ measurements should be interpreted with care, since artefacts such as shading may occur, resulting in measurement errors. The turbidity estimations of the AlgaeTorch are not accurate enough for the determination of turbidity as a water quality parameter.

In this study, the torch was immersed to a depth of 20 $\mathrm{cm}$ at five sampling points once an hour, and triplicate measurements were performed at each point. The measurement series was performed once per week on both sides of the lake. Ten measurements were performed at different places to obtain average chlorophyll- $a$ levels for each side of the lake. Measurements were done in the same position each time (Fig. 2). The spatial concentration of cyanobacterial and total chlorophyll- $a$ results in the lake were represented using Surfer (v. 7.0, Golden Software Inc.), and statistical analyses were performed using SPSS (IBM, SPSS Inc.; version 19.0.0).

\section{Results}

Table 1 shows the maximum total chlorophyll-a levels as found in individual samples at the various locations and days of the investigation. The results generally show higher maximum values at the residential side of the lake, with a difference of more than a factor of two on 14 June and 25 July. 
Table 1. Maximum total chlorophyll- $a$ found in individual samples at the western (residential) and eastern (WULS-SGGW) side of Lake Powsinkowskie in 2012.

\begin{tabular}{|c|c|c|}
\hline & \multicolumn{2}{|c|}{$\begin{array}{r}\text { Maximum total chlorophyll-a level observed in } \\
\text { individual samples }(\mu \mathrm{g} / \mathrm{L})\end{array}$} \\
\hline Date & $\begin{array}{c}\text { Eastern (SGGW fields) } \\
\text { lake side }\end{array}$ & $\begin{array}{c}\text { Western (residential) } \\
\text { lake side }\end{array}$ \\
\hline 24 May & 41 & 57 \\
\hline 31 May & 28 & 36 \\
\hline 6 June & 24 & 52 \\
\hline 14 June & 66 & 137 \\
\hline 20 June & 37 & 35 \\
\hline 27 June & 40 & 41 \\
\hline 3 July & 21 & 29 \\
\hline 11 July & 38 & 65 \\
\hline 18 July & 47 & 71 \\
\hline 25 July & 44 & 93 \\
\hline
\end{tabular}

Fig. 3 shows the average results of cyanobacterial and total chlorophyll- $a$ for both the (western) residential side and the (eastern, WULS-SGGW) side of the lake (called "fields"). The results show that cyanobacteria comprised generally only a small portion of the total algal densities during the time of the investigations. The variability in the results was higher for the measurements performed on the residential side of the lake as shown by the larger bars, indicating the $95 \%$ confidence intervals of the results in Fig. 3B. This indicates a more patchy algal distribution.

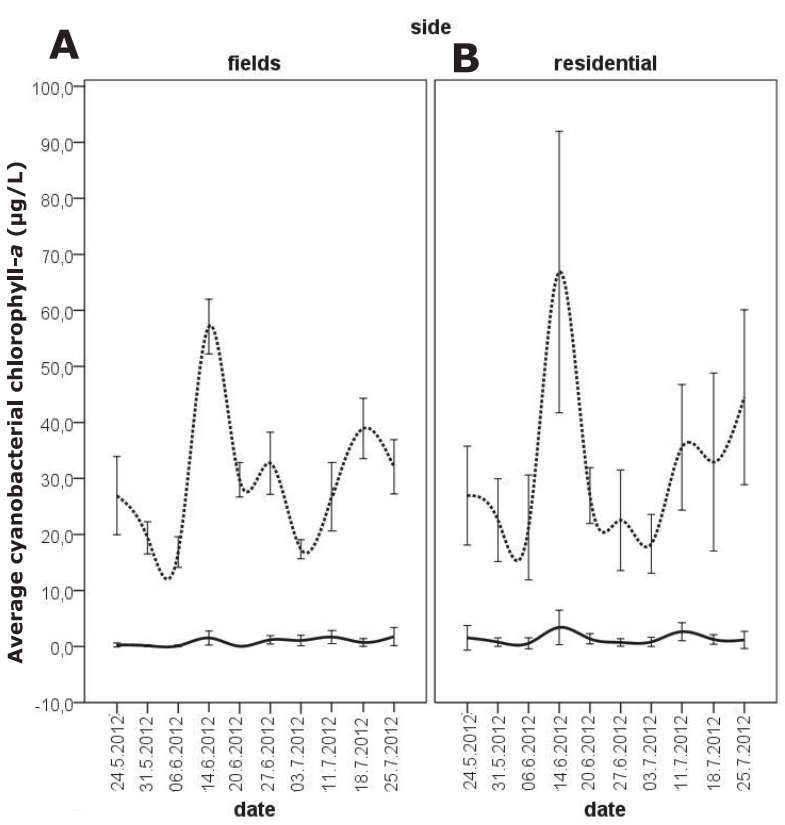

Fig. 3. Results of cyanobacterial (solid line) and total chlorophyll- $a$ (dotted line) for the SGGW side ("fields"; (A)) and the residential side (B) of Lake Powsinkowskie.
Within the alert level framework as described in [18], alert level 1 indicates that monitoring frequencies should be increased, and the lake should be checked regularly for scum-forming. Alert level 2 was not exceeded during the investigations (Fig. 4); this would have triggered a further increase in sampling frequencies, including microscopic analysis to determine species composition and, if necessary, toxin analysis. Fig. 4 shows the average cyanobacterial chlorophyll- $a$ levels for both the residential and the WULS-SGGW sides again, this time in relation to alert levels 1 and 2 (according to [18]). Figure 4B shows that the average cyanobacterial biomass exceeded alert level 1 twice at the residential side of the lake during the time of the investigations. The average cyanobacterial chlorophyll-a levels did not exceed alert level 2 on the WULS-SGGW side of the lake (Fig. 4A). The upper limits of the $95 \%$ confidence interval can be regarded as a worstcase situation. These upper limits exceeded alert level 1 on five dates on each side of the lake. Alert level 2 was exceeded by one upper limit on 14 June, on the residential side of the lake, thus indicating that cyanobacterial biomass has the potential to form harmful scum on at least one side of the lake.

\section{Discussion}

\section{Total Chlorophyll- $a$ Levels and General Degradation of the Ecosystem}

The highest algal densities were expected at the eastern (WULS-SGGW) side of the lake due to the use of fertilizers on the fields belonging to the university. However, the residential side showed overall higher algal densities. Algal densities vary in space and time, and the predominantly western winds in the summer period would have concentrated algal densities on the WULS-SGGW

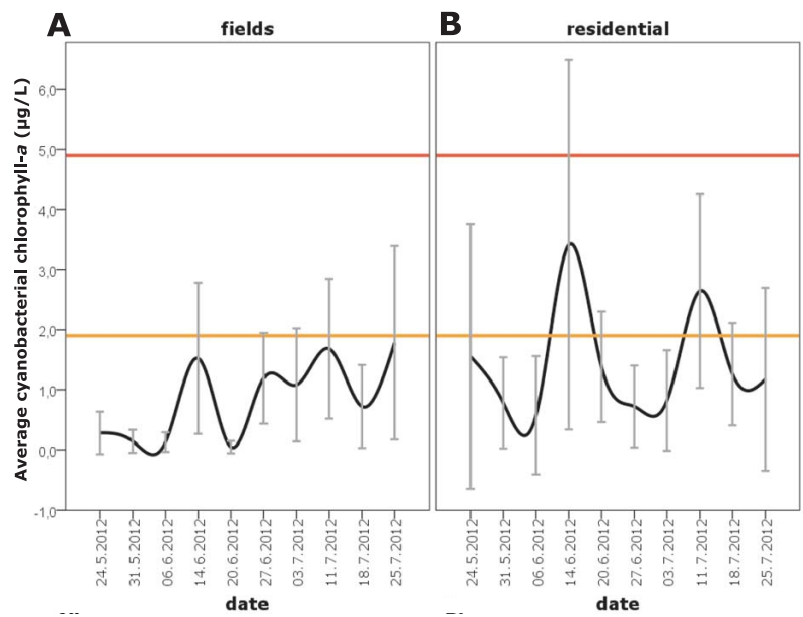

Fig. 4. Results of average cyanobacterial chlorophyll-a related to Alert Level $1(1.9 \mu \mathrm{g} / \mathrm{L}$ cyanobacterial chl.- $a$, yellow line $)$ and Alert Level 2 (4.9 $\mu \mathrm{g} / \mathrm{L}$ cyanobacterial chlorophyll-a, red line) for the WULS-SGGW side ("fields"; (A)) and the residential side (B) of Lake Powsinkowskie. 
side of the lake; however, this was not the case here. It seemed that the conditions on the residential side of the lake were more favourable for algal growth than on the WULS-SGGW side.

It is known that in Central/Eastern European countries and developing countries many people do not connect their houses to the wastewater network of the city but use their own cesspool. A further investigation of the residential side of Lake Powsinkowskie revealed that some of these cesspools were directly linked to the lake, as some drainage pipes were found from the residential area leading into the lake. It is also known that poorly functioning septic systems are a common source of nutrients, which can also stimulate algal blooms [26]. Additionally, in many urban areas, leaching of nutrients from land to water is a significant and growing problem [27]. Since dense algal growths depend on high amounts of nutrients, they are favoured by nutrient input from land, thus leading to the increasing intensity and frequency of blooms in lakes and estuarine waters [28]. These factors may have caused the increase in total chlorophyll- $a$ levels on the residential side of the lake.

Koperski [3] concluded that Lake Powsinkowskie is currently the richest freshwater environment in the Warsaw area in terms of species richness and rarity, and also one of the richest lakes in Poland. However, increased pressure from human activities can threaten the ecosystem's integrity and lead to the loss of valuable species. Poland does not have a tradition of involving the public at large in environmental programmes, e.g., regarding aquatic ecosystems in cities [28], but the findings of this study indicate that a reduction in nutrient loading into the lake can be achieved simply by informing the local residents about the effects of draining cesspools directly into the lake. Studies such as the one performed here can help to illustrate the effects of such measures, and provide a sound scientific basis for making policy determinations and implementing risk management strategies. Hudnell [8] (Fig. 5) concluded that a successful and sustainable

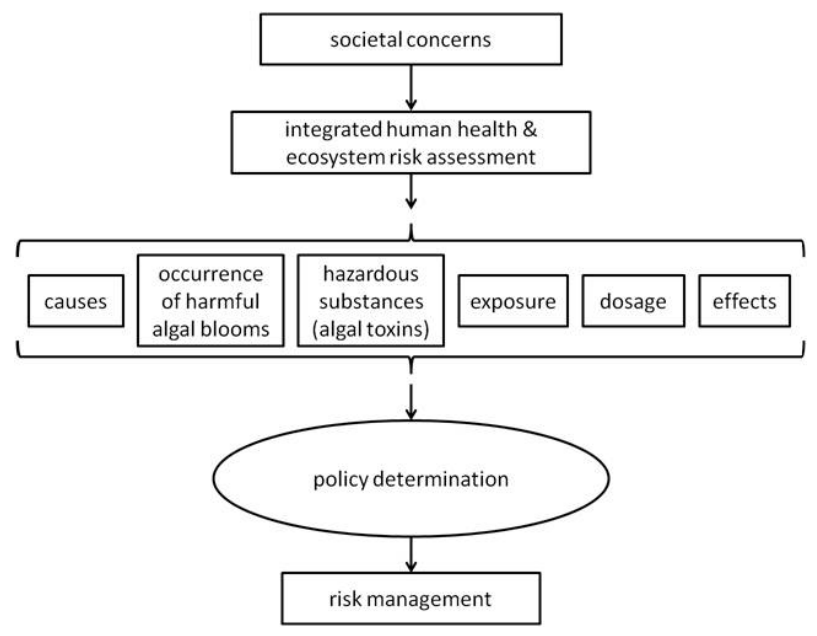

Fig. 5. Systematic approach to freshwater harmful algal blooms, as described in [8]. approach towards the assessment and mitigation of risks related to freshwater (harmful) algal blooms will strengthen local economies while at the same time protecting human and animal health and aquatic ecosystems.

Climate change scenarios predict that rivers, lakes, and reservoirs will experience increased temperatures, more intense and longer periods of thermal stratification, modified hydrology, and altered nutrient loading [29, 30]. These environmental changes will have additional effects on freshwater phytoplankton species composition and biomass, potentially favouring cyanobacteria over other phytoplankton [31]. Poland is currently already facing a serious shortage of water resources [32], caused on the one hand by the regional climatic conditions and on the other hand by adverse actions that have further reduced the already limited retention of freshwater. This has resulted in an aggravated water deficit in the country. Water management strategies should, however, not only be focused on water quantity, but include measures to reduce a further deterioration in water quality.

\section{Cyanobacterial Chlorophyll- $a$ Levels and Public Health Risks}

The monitoring of cyanobacteria is of growing interest because of its potential public health risk, as has been shown in $[7,11]$. Real-time monitoring of cyanobacteria using field fluorometers can serve as an early warning system for potentially hazardous conditions. Different types of fluorescence instruments used to detect the in vivo fluorescence of cyanobacterial pigments in natural waters have been developed and are used for monitoring potentially toxic cyanobacteria [33]. The alert level framework based on cyanobacterial chlorophyll- $a$ levels [18] is a rapid and easily applicable method for determining the severity of cyanobacterial developments using in situ fluorometry. An additional advantage is the possibility to determine both total algal biomass and cyanobacterial biomass simultaneously, resulting in a direct indication of the health risks caused by eutrophication effects in the lake.

According to [34], maximum chlorophyll-a levels as found in Lake Powsinkowskie (Table 1) clearly indicate the eutrophic state of this lake. Besides aesthetic problems (taste and odour) and the risk of low oxygen levels resulting in fish kills, it is likely that harmful algal blooms will occur under these conditions [8]. Although the results of Lake Powsinkowskie in 2012 do not indicate an immediate cause for concern regarding the cyanobacterial chlorophyll- $a$ levels found, further investigations are recommended to identify the nature of cyanobacterial developments in the lake. The investigations were performed from May until the end of July. However, the highest cyanobacterial densities would have been expected towards the end of the summer. Unfortunately, it was impossible to continue the measurements after July 2012, so the highest densities were probably not observed and may have occurred in August-September 2012. 


\section{Conclusions}

This study shows that an indication of the overall effects of eutrophication on algal growth and the potential risk of the presence of toxic cyanobacteria can easily be obtained with relatively simple simultaneous measurements of total and cyanobacterial chlorophyll- $a$. This information can be used by local authorities to increase public awareness of the effects of human activities in and around the lake, and illustrate how they can contribute to the conservation of important freshwater ecosystems such as Lake Powsinkowskie. Given the expected effects of climate change in this region, careful urban water management in which the public is actively involved becomes increasingly important for ecosystem conservation of the urban lakes in and around Warsaw.

\section{Acknowledgements}

The authors would like to thank Dr. Detlev Lohse of bbe Moldaenke GmbH (Germany) for his scientific support and advice in carrying out this work, and for lending the AlgaeTorch instrument used in the experiment, which allowed us to provide simultaneous quantification of the chlorophyll- $a$ content of cyanobacteria and the total chlorophyll content of microalgae in water. The authors would also like to thank Colin Moore of International English Services (Netherlands) for providing language checking and enhancement.

\section{References}

1. ZALEWSKI M. Ecohydrology - the use of water and ecosystem processes for healthy urban environments. International Symposium on New Directions in Urban Water Management UNESCO Paris, http://www2.gtz. de/Dokumente/oe44/ecosan/en-ecohydrology-waterecosystem-urban-2007.pdf, 2007.

2. VOS A. T., ROOS J.C. Causes and consequences of algal blooms in Loch Logan, an urban impoundment. Water SA 31 (3), 385-392, http://www.wrc.org.za, 2005.

3. KOPERSKI P. Urban environments as habitats for rare aquatic species: The case of leeches (Euhirudinea, Clitellata) in Warsaw freshwaters. Limnologica 40, 233, 2010.

4. MOORE J.W., SCHINDLER D.E., SCHEUERELL M.D., SMITH D., FRODGE J. Lake eutrophication at the urban fringe, Seattle Region, USA. Ambio 32 (1), 13, 2003.

5. DOBRZAŃSKA J., HEWELKE P. Environmental evaluation of chosen oxbow lakes of the Vistula in Warsaw. Infrastruktura i Ekologia Terenów Wiejskich 09, 65, 2010.

6. DODDS W.K., BOUSKA W.W., EITZMANN J.L., PILGER T.J., PITTS K.L., RILEY A.J., SCHLOESSER J.T., THORNBRUGH D.J. Eutrophication of U.S. freshwaters: Analysis of potential economic damages. Environ Sci Technol 43 (1), 12, 2009.

7. TARCZYŃSKA M., ROMANOWSKA-DUDA Z., JURCZAK T., ZALEWSKI M. Toxic cyanobacterial blooms in drinking water reservoir- causes, consequences and management strategy, Water Science and Technology: Water Supply, IWA Publishing 2001, 1 (2), 237, 2001.
8. HUDNELL H.K. The state of U.S. freshwater harmful algal blooms assessments, policy and legislation. Toxicon 55, 1024, 2010.

9. SHELLY K., HOLLAND D., BEARDALL J. Assessing Nutrient Status of Microalgae Using Chlorophyll- $a$ Fluorescence. In: D.J. Suggett et al. (eds.), Chlorophyll- $a$ Fluorescence in Aquatic Sciences: Methods and Applications, Developments in Applied Phycology 4, DOI 10.1007/978-90481-9268-7 11, (C) Springer Science+Business Media B.V., 2011.

10. ROMANOWSKA-DUDA Z., MANKIEWICZ J., TARCZYŃSKA M., WALTER Z., ZALEWSKI M.. The effect of toxic cyanobacteria (blue-green algae) on water plants and animal cells. Polish Journal of Environmental Studies Vol. 11 (5), 561, 2002

11. PAVLOVA V., BABICA P., TODOROVA D., BRATANOVA Z., MARSALEK B. Contamination of some reservoirs and lakes in Republic of Bulgaria by microcystins, Acta Hydroch Hydrob 34, 437, 2006.

12. DUY T.N., LAM P.K.S., SHAW G., CONNELL D.W. Toxicology and risk assessment of freshwater cyanobacterial (blue-green algal) toxins in water. Rev Environ Contam T 163, 113, 2000.

13. BLAHOVA L., BABICA P., MARSALKOVA E., MARSALEK B., BLAHA L. Concentrations and seasonal trends of extracellular microcystins in freshwaters of Czech Republic - results of the National monitoring Program. CLEANSoil Air Water 35 (4), 348, 2007.

14. OECD Guidelines for the Testing of Chemicals: Lemna sp. Growth Inhibition Test - Guideline 221, 2006.

15. JURCZAK T., TARCZYNSKA M., KARLSSON K., MERILUOTO J. Characterization and diversity of cyanobacterial hepatotoxins (microcystins) in blooms from Polish freshwaters identified by liquid chromatography-electrospray ionisation mass spectrometry. Chromatographia 59, 571, 2004.

16. TARCZYŃSKA M., NAŁĘCZ-JAWECKI G., ROMANOWSKA-DUDA Z., SAWICKI J., BEATTIE K., GODD G., ZALEWSKI M. Tests for the Toxicity Assessment of Cyanobacterial Bloom Samples. Environmental Toxicology, by John Wiley \& Sons, Inc., 16, 383, 2001.

17. BARTRAM J., BURCH M., FALCONER I.R., JONEM G., KUIPER-GOODMAN T. Situation assessment, planning and management. In: Chorus I., Bartram J. (Eds) Toxic Cyanobacteria in Water. A Guide to their Public Health Consequences, Monitoring and Management. E\&FN Spon on behalf of the World Health Organization, 179, 1999.

18. IZYDORCZYK K., CARPENTIER C., MROWCZYŃSKI J., WAGENVOORT A., JURCZAK T., TARCZYŃSKA M. Establishment of an Alert Level Framework for cyanobacteria in drinking water resources by using the Algae Online Analyser for monitoring cyanobacterial chlorophyll- $a$. Water Res 43, 989, 2009.

19. VAN PUIJENBROEK P.J.T.M., CLEIJ P., VISSER H. Aggregated indices for trends in eutrophication of different types of fresh water in the Netherlands. Ecol Indic 36, 456, 2014.

20. KRAUZE-TOMCZYK I., OSTROWSKI J. (Eds) Komisja Nazw Miejscowości i Obiektów Fizjograficznych [Commission Names of Places and Physiographic Objects]: Hydronimy, Wody stojące [Standing waters], Główny Urząd Geodezji i Kartografii [Head Office of Geodesy and Cartography], Warszawa, 2006

21. ROMANOWSKA-DUDA Z. B., GRZESIK M., KALAJI M. H. Physiological activity of energy plants fertilized with sevage sludge and usefulness of the Phytotoxkit test in practice. Environ Prot Eng 36 (1), 73-81, 2010. 
22. ROMANOWSKA-DUDA Z. B., KALAJI M. H., STRASSER R. Chlorophyll fluorescence as marker for heavy metals effects on water plants (Spirodela oligorrhiza). Pol J Nat Sci 1 (supplement): 213, 2003.

23. POBEL D., ROBIN J., HUMBERT J.F. Influence of sampling strategies on the monitoring of cyanobacteria in shallow lakes: Lessons from a case study in France. Water Research 45, 1005-1014, 2011.

24. BEUTLER M., WILTSHIRE K.H., MEYER B., MOLDAENKE C., LURING C., MEYERHOFER M., HANSEN U. P., DAU H. A fluorometric method for the differentiation of algal populations in vivo and in situ. Photosynth Res 72, 39, 2002.

25. KERÄNEN M., ARO E.M., NEVALAINEN O., TYYSTJÄRVI E. Toxic and non-toxic Nodularia strains can be distinguished from each other and from eukaryotic algae with chlorophyll fluorescence fingerprinting. In: Harmful Algae 8 (5), 817, 2009.

26. BACKER L.C. Cyanobacterial harmful algal blooms (CyanoHABs): Developing a public health response. Lake Reserv Manage 18 (1), 20, 2002.

27. STEHL-DELBANCO A., HANSSON L. A., GYLLSTRAM M. Recruitment of resting stages may induce blooms of Microcystis at low N:P ratios. J Plankton Res 25 (9), 1099, 2003.
28. PAERL H. Nuisance phytoplankton blooms in coastal, estuarine, and inland waters. Limnol Oceanogr 33 (4, part 2): 823, 1988.

29. NEWCOMBE G. Cyanobacteria: Impacts of climate change on occurrence, toxicity and water quality management. Water Res 46 (5), 1347, 2012.

30. PAERL H. W., PAUL V. J. Climate change: Links to global expansion of harmful cyanobacteria. Water Res 46 (5), 1349, 2012.

31. CAYELAN C. C., IBELINGS B. W., HOFFMANND E. P., HAMILTONE D. P., BROOKES J. D. Eco-physiological adaptations that favour freshwater cyanobacteria in a changing climate. Water Res 46 (5), 1394, 2012.

32. SENDER W., MASLANKO W. Diversity of aquatic ecosystems in urban areas - public expectations. Transylv. Rev. Syst. Ecol. Res 16 (1), 125, 2014.

33. ZAMYADI A., MCQUAID N., PRЙVOST M., DORNER S. Monitoring of potentially toxic cyanobacteria using an online multi-probe in drinking water sources. J Environ Monitor 14 (2), 579, 2012.

34. WETZEL R.G. Limnology: Lake and River Ecosystems, 3rd edition, Academic Press, USA, 279, 2001. 
